\title{
Using Vignettes as Self-reflexivity in Narrative Research of Problematised History Pedagogy
}

\author{
PHILIPPA HUNTER \\ Department of Policy, Cultural \& Social Studies in Education, \\ Faculty of Education, University of Waikato, Hamilton, New Zealand
}

\begin{abstract}
This article focuses on the use of vignettes as an emergent dimension of narrative research writing. The author draws on doctoral research that problematised history curriculum and pedagogy with pre-service teachers in the context of secondary teacher education in New Zealand. Pedagogic crossings of history education sites, and negotiation of disciplinary boundaries were storied in the narrative research. A lived experience of curriculum continuity and change had shaped a critical pedagogy orientation in the author's theorising and practice. This featured a self-reflexivity of pedagogic identities including those of student, practitioner, and researcher. The narrative writing was conceptualised as a layered bricolage of academic socialisation, engagement with theory, and practitioner work. Accordingly, it proved unworkable to distance the author's lived experience and pedagogic identities from the narrative, for these lay at the heart of the research. Therefore, the styling of vignettes became a creative way to story self-reflexivity within academic writing. Vignettes were conceived as inside stories that recalled pedagogic voices and evoked themes of curriculum disturbance as transgression, and desire as re-imagined history curriculum.
\end{abstract}

\section{Introduction}

In this article I discuss ways vignettes, as inside stories, re-imagined pedagogic experience within $\mathrm{PhD}$ narrative research writing. My project of problematising history pedagogy in a postgraduate curriculum class was situated in a New Zealand secondary teacher education programme as the narrative research case in point. I worked with a class of pre-service history teachers, in my teacher and researcher roles. As a history and social sciences teacher educator, my theorising and practice are informed by disciplinary crossings perceived as active negotiation of knowledge and methodological boundaries. This involves the professional and intellectual work of history, social sciences, curriculum theory, and pedagogy in education. I conceptualise history as a consciousness of the past, as instability of time and space, as self-reflexivity and cultural production. The cultural work of history means that we 'participate in history both as actors and as narrators' (Trouillot, 1995, p. 2). This duality of participation involves the study of the past as lived experience, and as socially constituted narrative representation and interpretation. This is shaped by an interest in people's lives and encounters with literature, music, and visual media. As texts and performance, these retrieve the past to captivate and surprise me in the present.

Amidst the complexity of mediating practitioner and research discourses in the academy, I found that self-reflexivity took on an unanticipated life of its own in the narrative writing for my $\mathrm{PhD}$. As self-reflexivity, inside storying constituted the heart of the narrative research. As my research writing developed, vignettes of lived curriculum experience were layered within the narrative. A critical pedagogy stance reflected my professional engagement with curriculum as shifting through complicity, disturbance, and resistance. Finding a way into the research writing had proved elusive for a time. I recall Terry, a literary scholar (doctoral supervisor), prompting the 
writing with his mantra of 'tell it like a story'. This worked, and so I entered narrative research writing with an experimental vignette History Crossings: August 2007.

History Crossings: August 2007

I walk from Education towards Arts and Social Sciences. The pathway is a sharpened line that both separates and connects education and arts and social sciences faculties within the university. On this day, I sense my crossing embodies what has gone before, and holds a promise of what is to come. My seminar focuses on research findings about ways secondary school students engage with the peculiar culture and traditions of the history curriculum, and ways they conceptualise history. I carry the voices, metaphors, and images of teenage history students with me (Hunter $\&$ Farthing, 2007). For on this day, I have assumed the roles of advocate and emissary.

My audience includes staff from history, English, geography, media studies, and anthropology departments. I catch up with the professor of history, and renew contact with a former graduate I have taught - now employed as a history tutor. I meet a history teacher and friend working in the department as a teaching fellow. Participants of my 2007 history class are in attendance. Today they make their own crossings to engage as colleagues in a context of shared professional interest. The seminar ends with a stimulating conversation. I am impressed with the forthright and insightful contributions of the pre-service history teachers in this conversation. Time's up and I'm thanked for a presentation that 'was very challenging!'

Retracing my steps towards the School of Education, I deconstruct the seminar with mingled relief and elation. I reflect on the seminar as one small act of courage amongst many such acts in my teaching life. Once more I am conscious of the power of disturbance, and a reshaping of a territory for myself.

History Crossings contextualises my curriculum and practitioner work as a history and social sciences teacher educator within the university. The vignette signals the situated nature of the narrative research - the problematised history pedagogy as my PhD project. History Crossings also illustrates movement across history territories I mediate as a history and social sciences educator. The vignette uses first-person storying to recall a professional experience that connected many pedagogic identities such as teacher educator, pre-service history teachers, secondary school history students, and history scholars as colleagues. Through narration I interpret voices in a site of inquiry and bring to mind history's discursive production. Notions of time and space and a sense of reshaped territories are built into the inside story. History Crossings also assists me to begin the work of this article.

In sequencing this article, I introduce the nature of narrative, narrative research, the construction of narrative as bricolage, and inside storying through vignettes. Secondly, antecedents of my pedagogic identities, and a conception of curriculum as embodiment are discussed. Selfreflexivity is considered in relation to voice, narrative identities, pedagogy, and a continuity of curriculum as lived experience. Thirdly, as the narrative focuses on history as a curriculum problem, vignettes reveal tensions of competing curriculum discourses that play out in history pedagogy. In particular, discourses identified as scholar traditional, social reconstructionist, and social efficiency are storied in sites of history education. As curriculum tensions have shaped a critical pedagogy orientation, my inside stories offer glimpses of pedagogic disturbance and desire. Each part of the article includes vignettes that I styled into my $\mathrm{PhD}$ narrative research writing. Their intra-active dimensions are in turn storied within this article's narrative.

\section{Narrative Research, Bricolage, and Vignettes as Inside Stories}

Catherine Riessman has argued the 'absence of a single meaning' of narrative in working definitions in the human sciences $(2008$, p. 6). However, narratives reveal commonalities such as writers' agency; representation of voice and identities; contingency; emplotment; contextual features; shaping of time and space; and creativity in construction. Narrators make meaning to articulate a sense of contextual coherence for their readers and narrative is grounded in experiences of lived time. The philosopher Paul Ricoeur (1984) viewed narrative as the retrieval from the past of partial experience, which means its shaping draws from recollection and memory. In The Dialogic Imagination: four essays, Mikhail Bakhtin (1981) conceived temporal accounts in narratives as 
chronotopes (time-space). As literary conventions, chronotopes organise space and time relationships that intersect plot, storied events, and lived experience. I am intrigued by ways narratives are at once retrospective and prospective (Polkinghorne, 1988). Janus-like in gaze and transitions, narratives review lived experiences of the past and predict future possibilities. Jerome Bruner (2002) describes this process as dialectic meaning making - between what was expected and what came to pass. In the moment of constructing stories, time and space, memory and imagination become fused.

Narrative is claimed and theorised diversely within social sciences and humanities research traditions. In a review of research in education (1995-96) Kathleen Casey commented on the difficulty in framing narrative research within defined subject areas and institutional settings. The interdisciplinary attraction of narrative research is grounded in ways human beings make meaning through language (Bruner, 1986; Polkinghorne, 1988; Casey, 1995-96; Chase, 1996, 2005; Riessman, 2008). Susan Chase (2005) has conceptualised narrative research as an amalgam of interdisciplinary analytic lenses that revolve around the lived experiences of self-narrative. She acknowledges this complexity in a postmodern milieu. Matti Hyvarinen (2006) researched the idea of a conceptual history of narrative. He introduces narrative as a 'potentially contested' concept, 'travelling' from literature to social sciences, to law, policy, health, and theology, to name a few social fields. In exploring theoretical contradictions of narrative, researchers Corinne Squire, Molly Andrews and Maria Tamboukou (2008) conceive narrative as a popular 'portmanteau' term in contemporary social research (p. 5).

The 'narrative turn' in the social sciences shifted from traditional positivist stances to interpretive positioning with meaning becoming a central focus (Bruner, 1991). The idea of the 'narrative turn' seems inadequate in light of trying to unravel the language and disciplinary conventions of narrative theorising. I have experienced narrative theories and shifts as they have variously been absorbed or kept at bay in social sciences, history, and studies of literature. This has been part of my accidental academic construction. Clandinin and Connelly articulate narrative inquiry as 'both the phenomenon and the method of the social sciences' (2000, p. 18). In narrative research, stories are interwoven experiential texts and narrators become the embodiments of lived stories (Clandinin \& Connelly, 1996; 2000). The way Torill Moen describes narrative research resonates with my perception as a 'frame of reference, a way of reflecting during the entire inquiry process, a research method, and a mode for representing the research study' (2006, p. 2).

From the inception of the doctoral research, I was aware of my identities as a practitioner, researcher, and bricoleur (Lévi-Strauss, 1966). As a university student in the 1970s, the French social anthropologist Claude Lévi-Strauss' writing of Tristes Tropiques (1961) had captivated me. In his memoir of traveller's tales and ethnographic analyses, Lévi-Strauss poetically connected disciplinary insights including anthropology, history, and philosophy. In a later work The Savage Mind (1966), Lévi-Strauss conceptualised his notion of bricoleur as an adept person who uses all the tools available to put things together to complete a task. So I approached the narrative research as a bricoleur, to layer lived experience, perspectives, and pedagogy as a dynamic venture. This played to my strengths as a teacher educator. When reviewing research literature in search of ways to align theoretical gazes with pedagogy, further conceptions of bricolage proved helpful. These included Norman Denzin and Yvonna Lincoln's conceptualisation of bricolage as critical research innovation (2000), and Lincoln's thinking of bricolage as emancipatory discourse (2001). In a conceptualisation of the complex intertextual nature of bricolage, Joe Kincheloe, the Canadian theorist of critical pedagogy, commented: 'Bricoleurs are always aware that the researcher, the consumer/reader of the research, and exterior research narratives always occupy points on intersecting intertextual axes (2005, p. 325).

As a researcher, the storying of vignettes added texture to the bricolage of the narrative's writing. Vignettes became a device to illuminate pedagogic experiences. The term vignette comes from the French word vigne and means small vine. Vignettes are generally described as short stories, scenarios, depictions of situations, accounts using imagery, and recollection of actions. They are explored and styled contextually, and include visual or written texts. The storying of vignettes crept up on my writing. They flowed as a creative performance in the midst of theorised academic writing that Elbow (1981) has described as the process of critical writing. Whilst containing plots and structures themselves, vignettes are not isolated set pieces in the research writing. Beth Graue cites Laurel Richardson's thinking (1997) about vignettes as providing a 
'crystallization' of understanding for both the reader and the author (2006, p. 522). In my narrative research, vignettes are worded and read within a layered storying of problematised history curriculum and pedagogy as a case in point. The 'putting into words' of vignettes as inside stories involves similar writing processes to those found in autobiography, autoethnography, memoir, life storying, or aesthetic text. The vignette Echoed Lives can be read and interpreted through these processes. As an inside story Echoed Lives is styled as a reference point to my antecedents, identity, emotions, multiple voices, and entry into a dialogue with readers in this article's narrative as reflexive knowing (Creamer, 2006; Lutrell, 2010).

\section{Echoed Lives}

Images of my ancestors Janet and Archibald MacDonald hang in the Otago Settlers Museum. By 1851 Arch MacDonald had set up a small fee-paying school at the Anderson's Bay inlet on the Otago Peninsula. An over-painted Victorian daguerreotype reveals Janet and Arch in their middle years sitting awkwardly in an extraordinarily contrived studio setting. Janet resolute and fierce in jet-black bombazine complete with crested headdress, and Arch momentarily startled his translucent eyes envisioning perhaps, life beyond avocation and the snap of the shutter.

In the mid-1990s, my family revisited Janet $\&$ Arch in the museum. As our gazes met theirs we fought back the rising sense of fun and laughter that these portraits always evoked, yet felt a tug of awe and sense of discomfiture that our lives were perhaps made easier by their struggle. Our encounter with Janet and Arch linked all our pasts as an enjoined echo.

\section{Self-reflexivity, Narrative Identities, and Embodied Curriculum}

The glimpse of Janet and Arch in Echoed Lives invites thinking about family, pedagogic identities and envisioning of teaching lives. Echoed Lives embraces continuities and changes of lived experience of the past. Social conventions and pedagogic identities are re-imagined. My family life was lived amongst memories of teachers and educators whose values and agency assumed a kind of revered status. Paragons it seemed, and hard acts to follow. The inside storying of echoes of Scottish ancestry, teacher work, and family relations signals reflexivity around identity and embodied curriculum in the narrative research.

Whilst self-reflexivity is heightened in my use of vignettes, it is more than a 'self-conscious awareness' (Lutrell, 2010, p. 4). I borrow Wendy Lutrell's notion of 'reflexive knowing' (p. 4) to expand on this awareness. Lutrell, a qualitative methods scholar, points out that reflexivity is about 'making the research process and decision making visible at multiple levels: personal, methodological, theoretical, epistemological, ethical, and political. The reflexive practitioner attends to all levels' (p. 4). Reflexive knowing about discursive tensions that embed power relations in curriculum and pedagogy and compete for knowledge claims, shape my pedagogic stance. This 'knowing' also involves provisionality and uncertainty. The work of curriculum theorist Donald Schön comes to mind. In The Reflective Practitioner (1983) Schön focused on the importance of reflection in the learning process, and uncertainties as a source of learning (p. 300). Hence, the idea of 'expert' positioning in pedagogy is disturbed and problematised. I find the scholar Patti Lather's critically reflexive approach to research (1992) a helpful articulation. Lather called for researchers to 'keep things in process, to disrupt, to keep the system in play, to set up procedures to continuously demystify the realities we create, and to fight the tendency for our categories to congeal' (p. 12). Such thinking motivated me to problematise history pedagogy in my curriculum work, and settle on a narrative research design to do this.

Curriculum theorist William Pinar theorises self-reflexivity within processes of education (2004). He asserts that any reconceptualised curriculum begins with the subjective lessons of autobiographical experience (2004, p. 35). In Practice Makes Practice: a critical study of learning to teach (2003), Deborah Britzman advances Pinar's and Madeleine Grumet's thinking about the autobiographical curriculum, proposing a critical approach to methods of self-reflexivity. For Britzman, these make available the 'discursive practices necessary to the critical theorization of teachers' experiential continuum, their constructions of meaning, and their subjective development' (p. 66). 
In my narrative research, self-reflexivity involved deconstructing constructed realities of history curriculum, knowledge claims, and pedagogic identities. The following vignette Deconstruction is included here to convey an understanding of deconstruction - albeit in a personal sense.

Deconstruction: London, December 2007

Sitting in a café at the Tate Modern. It is late afternoon, almost dusk. The window in front of us looms huge as a leaden fingerprinted frame. I gaze through my reflection down towards the walkway's wildly swaying feathered birches, attracted by shifting accents of viridian and black leaves.

Harley asks, 'Hey Pip, can you see the EYE across the river?'

A suspended moment;

I adjust my gaze outwards to look through the window.

I respond without thinking: 'No, not yet, I am just trying to see through myself.'

Deconstruction recalls an afternoon's experience of art as constructions and representations of meaning. The gallery's stark exterior, aesthetic of viewing spaces, and disembodied hum of voices had evoked a heightened awareness of my surroundings. The inside story hints at subjective development. Self-reflexivity that lacks understandings of exterior contexts or contingent factors might be critiqued as a self-absorbed pursuit, cult of self (Riessman, 2008), catharsis (Pillow, 2003), or narcissism (Bleakley, 2000). However, reflexivity does involve voice. Voice refers to how authors 'represent themselves and their participants in the texts they produce' (Hertz, 1997, as cited in Creamer, 2006, p. 529). Britzman's (2003) expansive conception of voice represents literal, metaphorical, and political dimensions. When styling vignettes, pedagogic voices enabled the inclusion of a cast of actors who shaped my educational identities. Whilst the process of renewing contact with past pedagogic experience proved surprisingly emotive, spaces opened up to voice identities in the research writing. The inside story of Mutability: Dunedin 1970s illustrates this work.

Mutability: Dunedin 1970s

A group of spirited sixth-form girls gathered in a science lab during a dismal wet lunchtime. As I recall, the context was biology revision prior to decisions announced informing us of who 'would not be required to sit the University Entrance Examination', hence to be granted matriculation. The lab was situated in a teaching block far removed from the staffroom. Mrs H, our raven-cloaked biology teacher with the incisive manner, treated us as the mature students she longed for. She had entrusted us to continue revision in her absence.

Along the windowed side of the lab was a row of sinks and above these were shelves holding labelled glass bottles of acids and sulphates. On sunny days the light caught the copper sulphate casting a blue shimmer over glass and benches. After we had a little play with these substances a not too out of the ordinary activity, some of us investigated the spoils in the resource cupboard. The weighty mercury jar materialised as an adamantine trophy, and with great hilarity we played with little pools of the liquid quicksilver on the high wooden benches. We freaked when the jar thudded over. The mercury slid heavily and singly as a fluid membrane across and over the bench, bouncing onto the floor as a skin-splitting myriad of shape-shifting refractive balls. The chaotic scramble to retrieve the mercury before Mrs H's return was viscerally fearfilled, yet comic.

Mutable mercury already transformed from cinnabar, was reconstituted this time as liquid multiple parts stemming from seeming coherence.

The unexpected turn in the course of a wet lunchtime's mischief is a vivid memory and reimagined experience. Mutability's metaphorical orientation includes linguistic devices and voicing to illustrate emplotment and storying pedagogy. The vignette's plot offers glimpses of the historical context of my secondary education that was situated in a traditional New Zealand girls' high school in the 1970s. Cultural expressions of curriculum are conveyed in the teachers' traditional academic dress, the ritual around assessment and university entrance as a higher academic qualification, and the material resources and teaching conditions of the science lab as classroom and form room. Curriculum players and pedagogical relationships are introduced with the group of senior girls and 
teacher. Established relations, respect, trust, and expectations of responsibility are turned upsidedown. The performative unfolding of the plot is mercurial itself as the reader is drawn into imagining and interpreting ideas alive in pedagogy such as trust, forbidden, transgression, excitement, and impending threat. The turn of events set in motion by the mercury spill activates a disruption in the story. This tension is also embodied in my personal and professional experiences as subjectivity in process and storied selves. Like the mercury, self is reconstituted through multiple experiences that shape pedagogic identities such as student, teacher, curriculum developer, emerging researcher, examiner, and supervisor. Social and political sources as 'power' also disturb, destabilise, and reshape narrative identity (Foucault, 1982; Lather, 1992; Ezzy, 1998; Bleakley, 2000; Naples, 2003; Chase, 2005; Miller, 2005). Pedagogic selves are revealed in power relations, gendered expectations and learners' assumptions.

Socially constructed roles and voices were storied in the $\mathrm{PhD}$ research writing. Narrative sociologists Holstein and Gubrium (2000) view narrative as 'identity bearing' within recognisable cultural frameworks (p. 13). Narrative conceptions of identity provide a subjective sense of selfcontinuity. Paul Ricoeur (as cited in Ezzy, 1998, p. 245), conceived self-identity as subjectivity that he explained as 'neither an incoherent set of events nor an immutable substantiality' impervious to context and social change. Cultural theorist Stuart Hall follows Julia Kristeva's 'subject in process', writing that 'identities are never completed, never finished; they are always, as subjectivity in process' (as cited in Kearney, 2003, p. 7). Therefore 'self can be re-imagined and remade, but is socially constructed and built on other people's responses and attitudes towards a person (Polkinghorne, 1988).

In the university environment, identities are always up for scrutiny and conjecture. Perceived as a teacher educator and emergent researcher, I choose to articulate identities in relation to feminist and postmodern orientations, and critical pedagogy. I do this in my search for spaces of professional and academic negotiation. At times it has felt uncomfortable to reveal selves as a childless educator within a profession of gendered assumptions and expectations (Britzman, 2003; Miller, 2005). On the other hand this identity can be constructed as liberating. Surprising happenings can open spaces for re-imagining identities. For example, the inside storying of Small Heartbeats recounts an educational experience that did just this in crossings of time zones, space, and cultural settings.

Small Heartbeats: Appokodu Village, Tamil Nadu, India 2001

It was a pristine January morning. A cool eucalyptus breeze cut the clearest of skies. Our group of educators was visiting a rural school in the Nilgris Hills. The whitewashed school with its startling turquoise window surrounds sat on baked earth. Students spilled out of windows and doors to dance and sing their welcome at the outdoors assembly. Our party then moved up the hill to meet the families who lived in the village closest to the school.

Musicians rhythmically drummed and trumpeted our arrival. Unfamiliar instruments flashed in the sunlight. Villagers lined the steep lane, joining us as we walked up to a central meeting space. I noticed a small domed temple nestled into the farmland below. Women wore fine bleached cotton tunics and shawls over richly coloured dresses. The youngest children clung to their mothers' clothing, and old weathered men and women sat closest to the action.

In a ritual similar to a powhiri's whaikorero [1] in Aotearoa New Zealand, the village and tour leaders exchanged speeches about educating the young. We danced with high aching arms and tightly interlaced fingers. After a meal of sweetened dhosa and milky cardamom tea, the band and its retinue of chanting villagers led us back to the bus.

As we walked back down the lane, a young couple stopped me and motioned me to hold their baby. Time stood still as the couple extended their arms to encircle us within. I am not sure what the gesture meant as we had little shared language other than the small heartbeats that between us spoke volumes ...

Small Heartbeats was an unfamiliar educational experience in which identities were unknown and open for imaginings. All senses came alive in a day of delight that had a profound personal impact. I find Petra Munro's Subject to Fiction: women teachers' life history narratives and the cultural politics of resistance a significant study (1998). Munro explored women's authoring of their teaching lives by 
letting go of her pre-determined theories to listen to the complex and contradictory ways three women teachers 'negotiated understandings of self against and with/in the dominant discourse of education and gender' (p. 27). Storied lives and feminist pedagogies speak directly to me with their concerns about emancipatory and inclusive approaches to teaching and learning. As responses to concerns about agency, and the sense of fragmentation many women teachers experience (Miller, 2005), these pedagogies aim to decentre authority in the classroom and invite political acts. These include resistances, silences, constructing narrative texts, self-storying, and dialogic exchanges.

Curriculum is conceived in this article as a fluid concept that signifies many meanings. It generally involves decision makers' ideas and beliefs about what counts and matters as knowledge for a society and its peoples in time and place. This presupposes a political positioning as interest groups vie to maintain or establish dominance through policy making. Curriculum can also be understood as a socio-cultural and interconnected process where beliefs and interactions constantly construct one another (Kincheloe, 2005). Curriculum intentions are interpreted and made sense of by teachers, and played out accordingly in pedagogy, evaluation and monitoring. A national history curriculum, for example, might be viewed as embodying ideology, intention, and action.

My conception of pedagogy is not simply a set of practices shaped by educational policy and historically situated aspects of curriculum. Pedagogy involves a relational and dialogic notion of teaching and learning (Van Manen, 1999; Lingard et al, 2003). I am influenced by the Australian educator Diana Mulcahy's conception of pedagogy as an 'emergent property or product of "intraaction" among persons, places, processes and things' (2006, p. 57). For Australian critical theorist Allan Luke, the concept of pedagogies reflects a diversity of theoretical foundations through three connected lines of approach he identifies as historical and theoretical discourses, material cultural practices, and structured actions (Luke, 2006, p. 4). Both Luke and Mulcahy theorise pedagogies as constructions that take social and material form. A further dimension of pedagogy acknowledges that the ways we do our work as teachers affect students' lives and expectations. In this sense, pedagogy is viewed as supporting intellectual engagement and connectedness to wider contexts to enhance ways of knowing (Hunter \& Farthing, 2007).

\section{The Curriculum Problem of History, Discursive Tensions and a Shift to Critical Pedagogy}

A Punctuated History is a snapshot of the history curriculum I experienced as a teenage schoolgirl in the 1970s as played out in pedagogy.

\section{A Punctuated History 1970s}

Mrs P taught us history in the sixth form. Always an assured presence in her thick skin of academic gown, she swept up and down the classroom's aisles whilst dictating the history from her textbook. No time to raise your head or think about what it all meant. Just keep on listening to catch the sequence of words spilling out from the text. This was history and the way it was done.

I recall a day close to school exams, when Mrs P handed back exercise books after marking to check that our history notes were sufficient. The class had been studying events in Europe leading to the outbreak of war in 1939. She had entered the room in an agitated state, having gathered momentum in her mad dash from staffroom to classroom. Her hair was static electricity, and her body heaved in indignation. As keen observers of all our women teachers, we knew the signals, and sat up as one in anticipation of the scene to come. Whilst ritual humiliation was to follow, we relished the drama.

Mrs P stalked with menace along the rows. She spat out her frustration.

'I can't believe your stupidity! What were you thinking? No I take that back, you are incapable of thinking in history. There are no history scholars in this class. I have checked your books all weekend and find most of them inadequate for examination preparation. Some of you are particularly dense. When I dictated your notes, I was punctuating by using the colon, but you wrote Poland! I meant colon NOT Poland!' 
A Punctuated History illustrates my experience of school history as the reproduction of cultural values through transmission of a single textual narrative. As a student I felt bewildered by the empty certitude of history's dictated facts: there had to be more! Mrs P's lament of our inability to faithfully record her dictated history, let alone understand the sequence of political events, said more about her pedagogic identity. When Mrs P confronted the evidence of the history she espoused in light of her traditional scholarly discourse, she was also dismayed. This approach to history pedagogy still lingers in some history programmes. Occasionally pre-service teachers voice their disturbance when encountering such practices during practicum experience. As a student, I had no prescience that I would be a history teacher one day. But I did perceive school history as a problem, disconnected from my interests and desire to enter imaginatively into the lived past.

Always in search of history, I experienced a transitional kind of educational curriculum as a university undergraduate. This bridged scholar traditional discourses of history through schooling through to university. The university curriculum was one of personal choice and desire that I unconsciously consumed. It was only after pulling together a conceptual framework for my PhD's narrative research, that I thought about the formative influence of university choices on my practitioner and research selves. In retrospect, I was fortunate to study social anthropology, and engage in thinking that today might be referred to as social constructivism in the social sciences field. This thinking projects visions of knowledge around structures, issues, social justice, social changes and social futures. I acknowledge that my pedagogy is influenced by critical reconstructionist discourses (Schubert, 2003). This means that curriculum thinking involves seeking resolution in values conflicts, endorsing ethical positioning, and critiquing the nature and purpose of curriculum. These discourses focus on teachers and students as agentive integrated social beings with the ability to interpret and seek a reconstructed society.

Discursive tensions that play out across the socially constructed nature and identity of history and the social sciences in the schooling curriculum have shaped my career and my pedagogic identities. The following vignette For Martin: choice and irregularity 1970s was written for Martin - a doctoral supervisor and scholar of educational policy. During the early writing of the research narrative, Martin sought clarification around my articulation of curriculum continuity in the narrative research. Accordingly, the vignette emerged as a response to indicate the nature of the university curriculum I experienced as a student. Incidentally, in seizing a freedom of choice around the scholarship of the day, no real thought was given to career considerations.

For Martin: choice and irregularity 1970 s

An invisible boundary marked out an irregular territory of university experiences. This was entered from the west by the bookshop, extended south by the library, east to the Arts buildings and theatres, and north alongside the River Leith and Registry. These markers defined activities and achievements. The central interior space known as the Union allowed freedom of movement and anonymity as personal choice. This was where drunken poets, fledgling protesters, and future commentators found voice and audience. It was also a place for a parade of lovers.

The space allowed for absorption of the scholarship of the day. Eclectic choices were consumed in preparation for regurgitation. I recall Tacitus and the rise and fall of Germania; Visigoths and rinderpest in Africa; the venerable Bede and the Anglo-Saxon Chronicles; Lévi-Strauss' Tristes Tropiques, Casteneda's separate reality, and Malinowski's sexual lives made academic.

Exit through the invisible boundary was always ameliorated by a return to the mystery of the fabulous University Bookshop. This was always the point of exit back into the hum of city life.

On reflection, the legacy of these formative movements across conceptual frameworks and methods of history and anthropology cannot be under-estimated. This irregularity of experience served to influence my curriculum thinking in light of blurred disciplinary genres, and approaches to pedagogy. After graduating from university I undertook a postgraduate teacher education programme, and started teaching in the early 1980s. However, it took three decades to question my sustained involvement with national history and social studies curriculum and assessment design and development. By 2004, the university's call for evidence of research performativity prompted me to research my increasing sense of curriculum disturbance, and desire for negotiating curriculum spaces where history's identity might be re-imagined in pedagogy (Hunter \& Farthing, $2004,2007,2008,2009)$. My doctoral research has attempted to pull apart the bits that informed my 
shift to problematised pedagogy in history teacher education. Accordingly, the research narrative attempts a coherence of storying these bits.

From a critical pedagogy perspective, curriculum policies and practices are viewed as conscious choices of action. In 'Border Pedagogy and the Politics of Postmodernism' (1995), critical theorist Henry Giroux challenges pedagogy that perpetuates dominant western male views of subjectivity, agency, and imperatives of nationalism. These challenges resonate with my critique of history pedagogy in the New Zealand curriculum. Giroux maintains that in the twenty-first century, we should not be 'constrained by modernist images of progress and history' (p. 38). In this sense postmodern pedagogies serve to 'deterritorialise the map of dominant cultural understanding' (p. 39). Giroux's thinking profoundly influenced my history pedagogy when undertaking research about history teachers' perceptions of 'their' history curriculum (Hunter $\&$ Farthing, 2004). Giroux's ideas of disruption and new reference points support Richard Bernstein's (1988, p. 267) call for pedagogies that promote 'healthy suspiciousness of all boundary-fixing and the hidden ways in which we subordinate, exclude, and marginalise' (as cited in Giroux, 1995, p. 40). Whilst I perceive critical history pedagogy as constructive, and valuing of the dignity of teachers and students, it also demands a questioning of our own assumptions and privilege. Problematised history pedagogy therefore sought counter-narratives, and 'trangressive' pedagogy (Shinew, 2001) to bring theory and practice into play (Hinchey, 2004).

The following three vignettes reveal history pedagogy in selected schooling contexts I negotiate as a teacher educator. 'I just want it to be nice Pip!' illuminates something of my critical reconstructionist approach to pedagogy. This discourse refers to the historical construction of the social (Yilmaz, 2007). For example, this approach involves attention to language, culture, representation, and engagement with issues of the past that focus history on human agency.

\section{'I just want it to be nice Pip!' Graduate History Curriculum Class 2004}

The pre-service history class was involved in interpreting historical sources of late nineteenthcentury immigration legislation. The use of evidence of New Zealand's parliamentary debates voiced political attitudes and discriminatory practices.

We discussed how history students in Year 13 senior programmes might explore the context, and ways the sources might be interpreted as representations of dominant cultural beliefs of racial superiority. Sussi, a student in her early twenties, became agitated and cried out: 'I just want it to be nice Pip! I haven't studied history like this...'

As a teacher educator of secondary history curriculum, I had attempted to interrogate the significance of late nineteenth-century issues of immigration, and consider ways racist attitudes of the time resonated with contemporary immigration debates. Sussi was disturbed by the way the history pedagogy confronted her views and teaching identity, and she was visibly upset. It is possible that Sussi's history teaching today may avoid any controversial or contested aspect of history. I ponder the impacts of such idiosyncratic approaches on students' thinking! For many experienced history teachers in the context of the New Zealand schooling curriculum, constructivist and critical discourses are generally considered as antithetical to 'real history'. Traditional approaches to history pedagogy remain buoyant in curriculum sites I move across. The vignette '... history's an intellectual subject ... !' 2009 stories discursive tensions in play in secondary schooling history.

'... history's an intellectual subject ... !' 2009

A co-researcher and I disseminated our research findings about senior secondary students' prevalent history discourses (Hunter $\&$ Farthing, 2009) to an audience of history teachers. Emerging findings of a discourse of students' antagonism towards New Zealand history appeared to confront and disturb many teachers present. Some teachers defended this discourse during question time. Predictably, audience responses turned to contextual preferences around New Zealand history, and the usual scapegoat of primary teachers and teachers of junior social studies turning kids off New Zealand history.

I was asked what might be done to engage student interest within the internally assessed part of the history programme. I suggested students could research contexts of their family or tribal histories. Furthermore, such engagement with lived experience in time and place offered 
interpretive possibilities in light of wider social, cultural, and political issues and historical representation. Alex, a history teacher and emerging leader with a decade’s experience took exception to this, and passionately retorted: 'Come on Pip, history’s an intellectual subject family history is not!'

Alex's traditional scholar discourse reveals pedagogic identity and a reluctance to open up alternative or counter-histories to all students. In this case history is conceptualised as an elite endeavour, closed to negotiation or students' preferences. Alex's perception of 'intellectual' is questionable if history pedagogy relies on dated textual narratives that may embed pre-constructed beliefs and uncritiqued transmission of official historical narratives (Hunter \& Farthing, 2009). The curriculum surveillance and compliances regulated by social efficiency discourses increasingly shape cultures of school history (Kelly et al, 2007). This is evident in New Zealand's enacted secondary schooling curriculum and assessment milieu where objectives and standards reconstitute a traditional form of events-based history. This school history diminishes thinking about human agency, or thinking about the nature and purpose of history (Hunter \& Farthing, 2009; Hunter 2011).

The third vignette involves tensions around professional identities in the history curriculum in education. 'She doesn't know anything about history' (2009) hints at the pedagogy of a pre-service history teacher, an experienced history associate teacher, and my pedagogy as a history teacher educator.

'She doesn't know anything about history' (2009)

This conversation took place during a school visit to observe and evaluate the history pedagogy of a pre-service teacher who had graduated with a recent Masters degree in history and politics. The history Associate Teacher was an experienced and confident practitioner.

Pip: 'How is Jana doing with her history teaching? Are you enjoying her creative approach?' History teacher (a look of incredulity and thoughts swiftly collected): 'Things are not going well at all.' Pip (heart sinking...): 'I'm concerned ... what's the problem? Is there an issue with her history preparation from the School of Education, her planning, relationships with students?'

History teacher: 'Well it's everything really...'

Pip (detecting malice - hence a terse reply): 'In terms of?'

History teacher (directs a challenging gaze): 'She lacks just about everything in her teaching. She doesn't know anything about history.'

Power relations are seen through history curriculum contexts and identities in the three inside stories, and signal disturbance when conceptions of history and practices are challenged. As insights into pedagogies, they may also be read in light of competing curriculum discourses I have identified within the article as scholar traditional, critical reconstructionist, and social efficiency. In 'She doesn't know anything about history' the history teacher's rejection of the pre-service teacher's pedagogy indicates professional disconnections and suspicion of history roles and motives. In this case the pre-service teacher did not measure up to teach history to the standards required by the teacher and shaped by assessment policy. Nor did I! This kind of encounter has shaped my critical pedagogy stance, and prompted $\mathrm{PhD}$ research that involved working with pre-service teachers to problematise history pedagogy and open spaces for counter-narratives. As a teacher educator I like to rethink professional practices, and re-imagine what history is, what history is for, and what history might become in a schooling curriculum. And this is why I embarked on narrative research of problematised history pedagogy.

\section{Closing Thoughts}

In narrative research writing, the emergent storying of vignettes took me by surprise but in the spirit of bricolage, I took the opportunity to experiment with lyrical writing of educational experience. As evocative inside stories, vignettes assisted me to make sense of, contextualise, and manage a complexity of theory. They became useful devices to signal transitions in the narrative, and as points of reference for layering problematised history pedagogy as critical praxis. Their use changed the styling of my narrative research in terms of demanding more thinking around selfreflexivity and subjectivity. This enabled a freedom of movement in the writing across time and 
space, to bring pedagogic identities and voices into being. As an intra-active dimension of academic writing, inside stories coloured and textured academic text and opened spaces for reflection and reimagining.

\section{Note}

[1] Aotearoa New Zealand's indigenous Maori people use powhiri as a cultural ritual to welcome Maori and diverse cultural groups to tribal places, political settings, and social occasions for the purpose of strengthening alliances, farewelling and honouring the dead, establishing or revisiting relationships, recalling tribal history and genealogy, etc. Whaikorero refers to the dialogue, songs and speeches that take place in a powhiri between hosts and visitors. Powhiri are part of New Zealand's cultural rituals, particularly in educational contexts.

\section{References}

Bakhtin, M. (1981) The Dialogic Imagination: four essays, edited by Michael Holquist, trans. C. Emmerson \& M. Holquist. Austin: University of Texas Press.

Bleakley, A. (2000) Writing with Invisible Ink: narrative, confessionalism and reflective practice, Reflective Practice, 1(1), 1-23. http:/ / dx.doi.org/10.1080/713693130

Britzman, D. (2003) Practice Makes Practice: a critical study of learning to teach, rev. edn. Albany: State University of New York Press.

Bruner, J. (1986) Actual Minds, Possible Worlds. Cambridge, MA: Harvard University Press.

Bruner, J. (1991) The Narrative Construction of Reality, Critical Inquiry, 18, 1-21. http: / / dx.doi.org/10.1086/448619

Bruner, J. (2002) Making Stories, Law Literature, Life. Cambridge, MA: Harvard University Press.

Casey, K. (1995-96) The New Narrative Research in Education, Review of Research in Education, 21, 211-253.

Chase, S.E. (1996) Personal Vulnerability and Interpretive Authority in Narrative Research, in R. Josselson (Ed.) Ethics and Process in the Narrative Study of Lives, vol. 4, pp. 45-59. Thousand Oaks, CA: Sage.

Chase, S. (2005) Narrative Inquiry: multiple lenses, approaches, voices, in N.K. Denzin \& Y.S. Lincoln (Eds) Sage Handbook of Qualitative Research: theory and method, 3rd edn, pp. 651-679. Thousand Oaks, CA: Sage.

Clandinin, J. \& Connelly, M. (1996) Teachers' Professional Knowledge Landscapes: teacher stories-stories of teachers-school stories-stories of schools, Educational Researcher, 25(3), 24-30.

Clandinin, J., \& Connelly, M. (2000) Narrative Inquiry: experience and story in qualitative research. San Francisco: Jossey-Bass.

Creamer, E. (2006) Experimenting with Voice and Reflexivity in Social Science Texts, in C. Conrad \& R. Stein (Eds) The Sage Handbook for Research in Education: engaging ideas and enriching inquiry, pp. 529-543. Thousand Oaks, CA: Sage.

Denzin, N.K. \& Lincoln, Y.S. (Eds) (2000) Handbook of Qualitative Research, 2nd edn. Thousand Oaks, CA: Sage.

Elbow, P. (1981) Writing with Power: techniques for mastering the writing process. New York: Oxford University Press.

Ezzy, D. (1998) Theorising Narrative Identity: symbolic interactionism and hermeneutics, The Sociological Quarterly, 39(2), 239-252. http:// dx.doi.org/10.1111/j.1533-8525.1998.tb00502.x

Foucault, M. (1982) The Subject and Power, in H. Dryfus \& P. Rabinow (Eds) Michel Foucault: beyond structuralism and hermeneutics. London: Harvester Wheatsheaf.

Giroux, H. (1995) Border Pedagogy and the Politics of Postmodernism, in P. McLaren (Ed.) Postmodernism, Postcolonialism and Pedagogy, pp. 37-65. Albert Park: James Nicholas.

Graue, B. (2006) Writing in Education Research, in C. Conrad \& R. Stein (Eds) The Sage Handbook for Research in Education: engaging ideas and enriching inquiry, pp. 515-529. Thousand Oaks, CA: Sage.

Hinchey, P. (2004) Becoming a Critical Educator: defining a classroom identity, designing a critical pedagogy. New York: Peter Lang.

Holstein, J. \& Gubrium, J. (2000) The Self We Live by: narrative identity in a postmodern world. Oxford: Oxford University Press. 
Hunter, P. (2011) Disturbing History's Identity in the New Zealand Curriculum to Free up Historical Thinking, Curriculum Matters, 7, 48-70.

Hunter, P. \& Farthing, B. (2004) Talking History: teachers' perceptions of 'their' curriculum in the context of history in the New Zealand curriculum 1980-2003. Hamilton: Wilf Malcolm Institute of Educational Research.

Hunter, P. \& Farthing, B. (2007) Connecting Learners with Their Pasts as a Way into History, set: Research Information for Teachers, 1, 21-27.

Hunter, P. \& Farthing B. (2008) Students Think History and Teachers Learn, set: Research Information for Teachers, 1, 15-22.

Hunter, P. \& Farthing, B. (2009) History Students Voice Their Thinking: an opening for professional conversations, set: Research Information for Teachers, 3, 52-59.

Hyvarinen, M. (2006) Towards a Conceptual History of Narrative, Studies Across Disciplines in the Humanities and Social Sciences, 1, 20-41. Helsinki: Collegium for Advanced Studies.

Kearney, C. (2003) The Monkey's Mask: identity, memory, narrative and voice. Stoke-on-Trent: Trentham Books.

Kelly, T., Meuwissen, K. \& Vansledright, B. (2007) What of History? Historical Knowledge within a System of Standards and Accountability, International Journal of Social Education, 22, 115-145.

Kincheloe, J. (2005) On to the Next Level: continuing the conceptualization of the bricolage, Qualitative Inquiry, 11(3), 323-350. http:/ / dx.doi.org/10.1177/1077800405275056

Lather, P. (1992) Post-critical Pedagogies: a feminist reading, in C. Luke \& J. Gore (Eds) Feminism and Critical Pedagogy. London: Routledge.

Lévi-Strauss, C. (1961) Tristes tropiques, trans. J. Russell. New York: Atheneum.

Lévi-Strauss, C. (1966) The Savage Mind. Chicago: University of Chicago Press.

Lincoln, Y.S. (2001) An Emerging New Bricoleur: promises and possibilities - a reaction to Joe Kincheloe's 'Describing the Bricloeur', Qualitative Inquiry, 7(6), 693-696. http: / / dx.doi.org/10.1177/107780040100700602

Lingard, B., Hayes, D. \& Mills, M. (2003) Teachers and Productive Pedagogies: contextualising, conceptualizing, utilizing, Pedagogy, Culture and Society, 11(3), 399-424. http: / / dx.doi.org/10.1080/14681360300200181

Luke, A. (2006) Editorial Introduction: Why Pedagogies? Pedagogies, 1(1), 1-6.

Lutrell, W. (2010) Introduction, in W. Lutrell (Ed.) Qualitative Educational Research: readings in reflexive methodology and transformative practice. New York: Routledge.

Miller, J. (2005) Sounds of Silence Breaking: women, autobiography, curriculum, vol. 1. New York: Peter Lang.

Moen, T. (2006) Reflections on the Narrative Research Approach, International Journal of Qualitative Methods, 5(4), 1-11. http://www.ualberta.ca/-ijqm/backissues/5_4/pdf/moen.pdf

Mulcahy, D. (2006) The Salience of Space for Pedagogy and Identity in Teacher Education: problem-based learning as a case in point, Pedagogy, Culture and Society, 14(1), 55-69. http: / / dx.doi.org/10.1080/14681360500487827

Munro, P. (1998) Subject to Fiction: women teachers' life history narratives and the cultural politics of resistance. Buckingham: Open University Press.

Naples, A. (2003) Feminism and Method: ethnography, discourse analysis and activist research. New York: Routledge.

Pillow, W. (2003) Confession, Catharsis, or Cure? Rethinking the Uses of Reflexivity as Methodological Power in Qualitative Research, Qualitative Studies in Education, 16(2), 175-196. http: / / dx.doi.org/10.1080/0951839032000060635

Pinar, W. (2004) What is Curriculum Theory? Mahwah, NJ: Lawrence Erlbaum Associates.

Polkinghorne, D. (1988) Narrative Knowing and the Human Sciences. New York: State University of New York Press.

Richardson, L. (1997) Fields of Play: constructing an academic life. Piscataway, NJ: Rutgers University Press.

Ricoeur, P. (1984) Time and Narrative, trans. K. McLaughlin \& D. Pellauer, vols $1 \& 2$. Chicago: University of Chicago Press.

Riessman, C.K. (2008) Narrative Methods for the Human Sciences. Thousand Oaks, CA: Sage.

Schön, D. (1983) The Reflective Practitioner: how professionals think in action. New York: Basic Books.

Schubert, W. (2003) The Curriculum-curriculum: experiences in teaching curriculum, Curriculum and Teaching Dialogue, 5(1), 9-21. 
Shinew, D. (2001) 'Disrupt, Transgress, and Invent Possibilities': feminists' interpretations of educating for democratic citizenship, Theory and Research in Social Education, 29(5), 488-512.

Squire, C., Andrews, M. \& Tamboukou, M. (2008) Introduction: What is Narrative Research? In C. Squire, M. Andrews \& M. Tamboukou (Eds) Doing Narrative Research, pp. 1-44. London: Sage.

http: / / roar.uel.ac.uk/jspui/handle/10552/1148

Trouillet, M. (1995) Silencing the Past: power and the production of history. Boston: Beacon Press.

Van Manen, M. (1999) The Language of Pedagogy and Primacy of Student Experience, in J. Loughran (Ed.) Researching Teaching: methodologies and practices for understanding pedagogy, pp. 13-27. London: Falmer Press.

Yilmaz, K. (2007) Introducing the Linguistic Turn to History Education [electronic version], International Education Journal, 8, 270-278.

PHILIPPA HUNTER is a senior lecturer in history and social sciences education, and curriculum studies at the Faculty of Education, University of Waikato, New Zealand. She has been a primary and secondary teacher, and has a background of extensive involvement with the New Zealand Ministry of Education, and the New Zealand Qualifications Authority's social sciences curriculum and assessment policy developments. Philippa's research interests involve critical pedagogy in her teaching of history in postgraduate secondary teacher education, and narrative research of problematised history pedagogy.Correspondence: phunter@waikato.ac.nz 